Article

\title{
Accuracy Assessments of Local and Global Forest Change Data to Estimate Annual Disturbances in Temperate Forests
}

\author{
Katsuto Shimizu ${ }^{1, *(D)}$, Tetsuji Ota ${ }^{2}$ and Nobuya Mizoue ${ }^{2}$ (I) \\ 1 Forestry and Forest Products Research Institute, 1 Matsunosato, Tsukuba, Ibaraki 305-8687, Japan \\ 2 Faculty of Agriculture, Kyushu University, 744 Motooka, Fukuoka 819-0395, Japan; \\ ota.tetsuji.887@m.kyushu-u.ac.jp (T.O.); mizoue@agr.kyushu-u.ac.jp (N.M.) \\ * Correspondence: katsutoshimizu@ffpri.affrc.go.jp
}

Received: 10 July 2020; Accepted: 27 July 2020; Published: 29 July 2020

check for updates

\begin{abstract}
Forest disturbances are generally estimated using globally available forest change maps or locally calibrated disturbance maps. The choice of disturbance map depends on the trade-offs among the detection accuracy, processing time, and expert knowledge. However, the accuracy differences between global and local maps have still not been fully investigated; therefore, their optimal use for estimating forest disturbances has not been clarified. This study assesses the annual forest disturbance detection of an available Global Forest Change map and a local disturbance map based on a Landsat temporal segmentation algorithm in areas dominated by harvest disturbances. We assess the forest disturbance detection accuracies based on two reference datasets in each year. We also use a polygon-based assessment to investigate the thematic accuracy based on each disturbance patch. As a result, we found that the producer's and user's accuracies of disturbances in the Global Forest Change map were 30.1-76.8\% and 50.5-90.2\%, respectively, for 2001-2017, which corresponded to $78.3-92.5 \%$ and $88.8-97.1 \%$, respectively in the local disturbance map. These values indicate that the local disturbance map achieved more stable and higher accuracies. The polygon-based assessment showed that larger disturbances were likely to be accurately detected in both maps; however, more small-scale disturbances were at least partially detected by the Global Forest Change map with a higher commission error. Overall, the local disturbance map had higher forest disturbance detection accuracies. However, for forest disturbances larger than 3 ha, the Global Forest Change map achieved comparable accuracies. In conclusion, the Global Forest Change map can be used to detect larger forest disturbances, but it should be used cautiously because of the substantial commission error for small-scale disturbances and yearly variations in estimated areas and accuracies.
\end{abstract}

Keywords: accuracy assessment; annual disturbance; Hansen Global Forest Change; disturbance size; polygon-based validation

\section{Introduction}

Forest disturbances largely influence the forest structure, biodiversity, and global carbon cycle [1-5]; hence, characterizing the spatial and temporal dynamics of forest disturbances is a key component of regional- and national-scale forest management $[6,7]$. Satellite data provide valuable information for deriving forest changes over large scales because of spatially and temporally consistent observations. Landsat data have especially been used to monitor deforestation, forest degradation, and forest disturbances in annual or more frequent time steps [8,9]. After the opening of the United States Geological Survey Landsat archives, many studies attempted to exploit long-term Landsat time-series data for forest change characterization at a 30-m spatial resolution [10]. Accordingly, automated 
disturbance detection algorithms based on the Landsat time-series data, which apply to regional- and national-scale forest disturbance detection, were proposed (e.g., [11-20]).

Forest disturbance estimation can be mainly performed using the following two approaches: generation of local disturbance maps based on satellite data and usage of forest change datasets that are already available. Local disturbance maps can be calibrated to local environments and cover different types of disturbances in regions of interest; thus, they usually provide accurate estimates and reduce the sample size in the validation process [8]. In addition, local disturbance maps can be further used for other study objectives, such as the attribution of forest disturbances (e.g., [13,21-26]), estimation of forest stand parameters (e.g., [27-33]), and land cover classification (e.g., [34]). However, the generation of local disturbance maps requires extensive knowledge, computational resources, and processing time, which are barriers for communities not specializing in remote sensing [35]. On the contrary, forest change datasets that provide the spatial and temporal dynamics of forest disturbances based on satellite data at a global scale are readily available to these communities. The Global Forest Change map developed by Hansen et al. [36] provides tree cover, forest loss, gain, and annual forest loss year at a 30-m spatial resolution. This dataset is widely used in various analyses [37] and can be used for regional disturbance detection. However, its accuracy might vary regionally because of different change dynamics and data availability [8]. In this context, trade-offs exist between the accuracy and the usability of the local disturbance map and the Global Forest Change map when estimating regional forest disturbances.

The disturbance detection accuracy is a key factor when choosing the Global Forest Change map and the local disturbance map. Researchers must understand the accuracy differences in these maps when determining which map to use. Although previous studies assessed the tree cover of the Global Forest Change map for forest area estimation [38-41], the accuracy of annual forest disturbance detection was rarely assessed. Accuracies using the Global Forest Change map might vary in different years. The detected disturbance area might considerably differ across years as well [42,43]. The differences in the detection accuracies should be investigated on an annual basis to evaluate the performance of different disturbance maps. However, previous studies were often based on the accuracy comparisons between the Global Forest Change map and the local disturbance map on the entire study period (e.g., [44,45]). Several studies compared the temporal variations of the estimated disturbance area (e.g., [44,46]), but did not conduct an annual accuracy assessment. The disturbance detection accuracy should be compared yearly to provide insights on the use of the Global Forest Change map and the local disturbance map.

The accuracy assessment generally requires sample-based reference data to estimate the area, accuracies, and uncertainties of the entire study area [47]. The methods for assessing accuracies and estimating the area of land change based on error matrices are well established (e.g., [48-50]). Low accuracy and estimated biases in disturbance maps can be compensated for in such accuracy assessment protocols with reference data [8]. However, these methods only provide a map accuracy for the entire study area [47], not the spatial variations of accuracy (e.g., omission error variations at different disturbance sizes). Understanding the spatial variations of the detection accuracy is important because disturbance maps are sometimes used to analyze spatial relationships. For example, the effectiveness of protected areas and community forestry for forest conservation was assessed using the Global Forest Change map (e.g., [51-53]). One approach for assessing the detection accuracy of each disturbance is the polygon-based assessment that uses a spatial overlap of the detected disturbances with reference disturbance patches [54]. Although this approach requires spatially contiguous reference data, it allows us to assess the detection accuracy at each disturbance patch and different patch sizes. The detection accuracy for different disturbance sizes might largely influence the accuracies and use of disturbance maps, especially in areas dominated by small-scale forest disturbances.

The influencing factors of disturbance detection bring other implications on the accuracy assessment. The spatial distribution of the correct detection and omission of disturbances is inevitably affected by several factors, including different vegetation, change agents, and satellite data availability 
across regions. Identifying such factors can provide clues for improving the detection accuracy and insights for potential errors in further analyses using disturbance maps. Although several factors (e.g., disturbance patch size and change magnitude $[45,55,56])$ are empirically recognized, a more robust approach based on statistical modeling is still lacking. The statistical analysis on potential factors, including topographic, spectral, and spatial variables, would inform the comprehensive interpretation of the disturbance detection accuracy.

This study aims to assess the accuracy of annual disturbance detection using the Global Forest Change map developed by Hansen et al. [36] and a local disturbance map developed in the study area dominated by harvest disturbances. Specifically, we investigate the following points: (1) accuracy of the annual disturbance detection using sample-based reference data with a 30-m spatial resolution for assessing the entire study period and 10-m spatial resolution for assessing the effects of mixed pixels; (2) detection accuracy at each disturbance using the polygon-based accuracy assessment; (3) influencing factors for correct disturbance detection and omission based on mixed-effect models with topographic, spatial, and spectral variables. By doing so, we suggest under what conditions either the Global Forest Change map or the local disturbance map should be used for efficient regional forest monitoring.

\section{Materials and Methods}

\subsection{Study Area}

The study area was the main island of Kyushu, Japan (Figure 1). A total land area of 3.85 million ha was used for the analyses. Approximately $64 \%$ of the land area of the study area is covered with forests dominated by Japanese cedar (Cryptomeria japonica), Japanese cypress (Chamaecyparis obtusa), and other broadleaf species (e.g., Quercus glauca, Quercus acutissima, Machilus thunbergii, Quercus serrata, and Castanopsis sieboldii). The mean annual temperature is $17^{\circ} \mathrm{C}$ with an average annual rainfall of $1660 \mathrm{~mm}$ in Fukuoka, which is the city in the northern part of the study area, and $19^{\circ} \mathrm{C}$ with an average annual rainfall of $2370 \mathrm{~mm}$ in Kagoshima, which is the city in the southern part of the study area. The elevation ranges from 0 to $1791 \mathrm{~m}$ above the sea level. In the last several decades, a harvesting operation mainly by clear-cut has been active in the southern part of the study area, especially in the Miyazaki, Kumamoto, and Kagoshima prefectures. This harvesting operation has been a dominant disturbance agent in the study area. In some regions, forests have also been affected by windthrows and landslides caused by typhoons and heavy rain.

\subsection{Global Forest Change Map}

The Global Forest Change dataset (version 1.7) developed by Hansen et al. [36] was used. It contains tree cover in 2000, forest loss, forest gain, and loss year layers. The forest loss year layer was clipped to the study area. The loss year 2001-2017 was used to represent the forest disturbances in the study period. A forest mask was not applied to the forest loss herein.

\subsection{Local Disturbance Map}

A local disturbance map developed by Shimizu et al. [57] in this region was used. The map was developed by using a random forest (RF) classification based on the LandTrendr temporal segmentation [11,58] executed on the Google Earth Engine (GEE) [59]. The methods used to develop the disturbance map are briefly described herein. First, the Landsat surface reflectance (SR) data from 1984 to 2018 were used to generate annual median composites. After converting the annual SR median composites to tasseled cap and other spectral indices, the LandTrendr temporal segmentation was implemented to extract the predictor variables in each year. The predictor variables and training samples were then used for the RF classification of four land cover change classes (i.e., forest harvesting, other disturbances, stable forest, and other cover changes). The derivation of the predictor variables and the implementation of RF classification were based on a direct prediction method presented in [60]. The forest harvesting and other disturbance patches less than four pixels were removed to reduce 
the commission errors. If two-year consecutive forest harvesting or other disturbances existed in the same pixel location, those in the latter year were removed. In this study, the four change classes were reclassed to disturbance and no-disturbance. The disturbances that occurred in 2001-2017 were used to coincide with the study period of the Global Forest Change map.

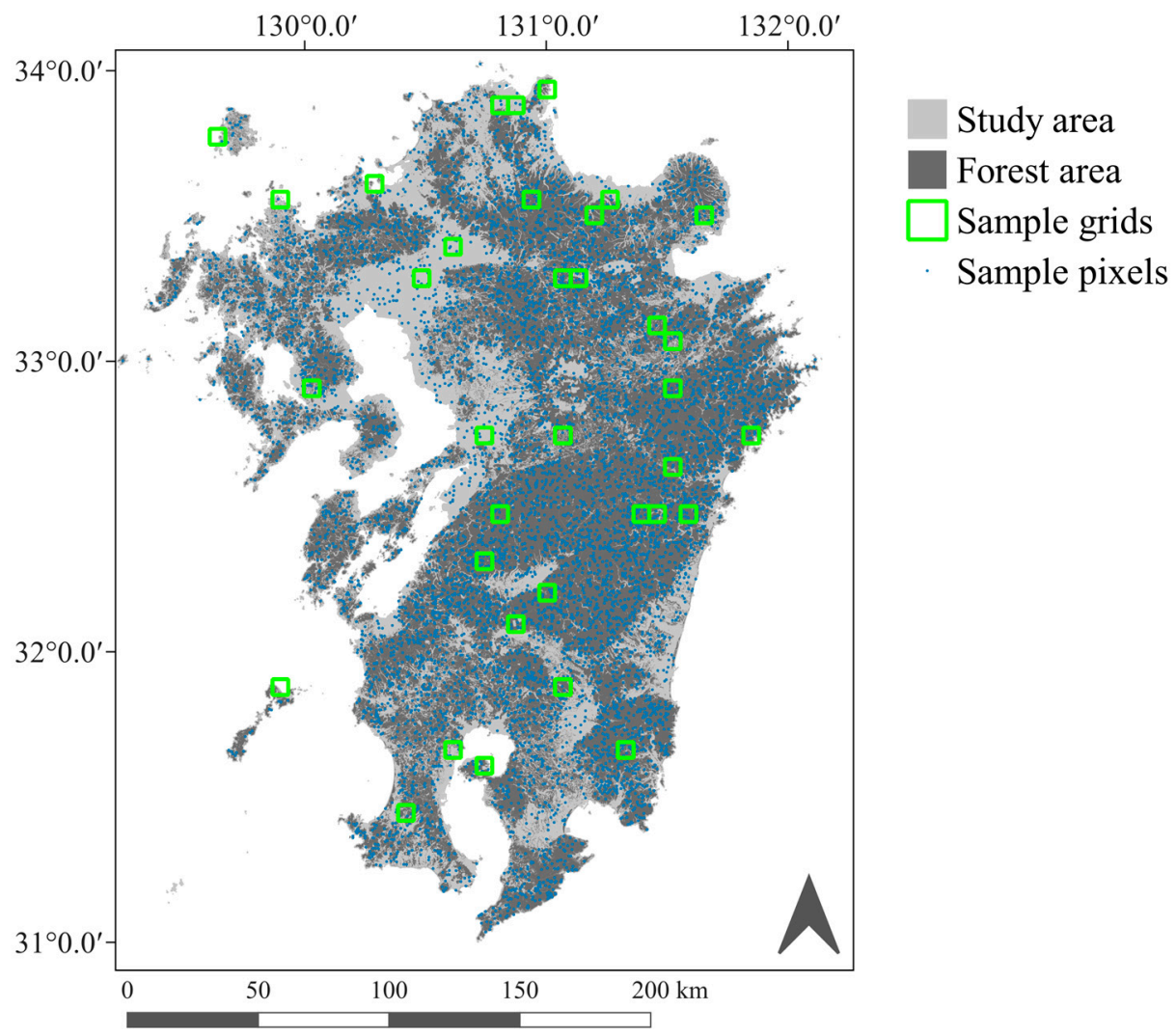

Figure 1. Study area. The land and forest areas were provided by the National Land Numerical Information (https://nlftp.mlit.go.jp/ksj/index.html). The sample grids and pixels represent the sample distribution in the accuracy assessment.

\subsection{Landsat, Sentinel-2, and SRTM DEM for Reference Data Collection and Model Building}

Landsat 5, 7, and 8SR data from 2000 to 2018 with a cloud cover less than $70 \%$ were used to generate annual median composites. These composite images were downloaded from GEE. The individual scenes of Landsat SR data from 2013 to 2018 were also downloaded. The annual median composites of the Sentinel-2 top of atmosphere (TOA) reflectance data were generated and downloaded from GEE using the Sentinel-2 data from 2013 to 2018 with less than 70\% cloud cover. The Normalized Burn Ratio (NBR), Tasseled Cap Wetness (TCW), and Angle (TCA) [61] were calculated for visual interpretation in Section 2.5 using Landsat annual median composites 2000-2018. The NBR was used to calculate the predictor variables in the mixed-effect models (Section 2.7). The elevation data from the Shuttle Radar Topography Mission (SRTM) Digital Elevation Model (DEM) [62] in GEE was used to calculate the topographic elevation and the slope in the mixed-effect models.

\subsection{Reference Sample Collection}

Two reference sample data were collected for accuracy assessments: one for the pixel-based reference data in 2001-2017 at a 30-m spatial resolution and the other for the reference data of $6 \times 6 \mathrm{~km}$ grids in 2013-2017 at a 10-m spatial resolution. Higher spatial resolution data are desirable for accurate accuracy assessment and the investigation of the effects of mixed pixels of disturbance detection; however, high-spatial-resolution data are only available for recent years. Therefore, in this study, 
the 30-m spatial resolution reference data were collected to assess the entire study period using Landsat data. The reference data of the $10-\mathrm{m}$ spatial resolution was collected using the Sentinel-2 data for recent years. All pixels in both reference data were used to assess the accuracy of the annual forest disturbance detection. The sample grid reference data was further used for the polygon-based assessment and mixed-effect modeling.

\subsubsection{Pixel-Based Reference Data for 2001-2017 at a 30 m Spatial Resolution}

Pixel-based reference samples were collected using a stratified random sampling approach. Based on the original local disturbance map, a total of 9000-pixel locations were selected from four strata (i.e., 2500 for harvested, 500 for other disturbed, 5000 for the stable forest, and 1000 for other changes pixels) for visual interpretation. Although Arévalo et al. [63] indicated that a sample selection of different sample locations in each change period can achieve better precision, the reference samples in this study were collected in the same location across all years because of the labeling efficiency in the visual interpretation $[47,64]$. We implemented the visual interpretation to label the change classes (i.e., disturbance or no-disturbance) of these samples in each year in 2001-2017. We used the Landsat time series composite images in each year, the trajectory of the spectral indices of the Landsat time series, and high-resolution satellite images in Google Earth to label disturbance or no-disturbance (Figure 2). As a result, 9000 reference pixels were collected at a $30 \mathrm{~m}$ spatial resolution in each year. The map classes of both maps were different from the strata; thus, a ratio estimator [65] was used to calculate the unbiased accuracy metrics in the accuracy assessment that follows.

(a) Landsat spectral index trajectory

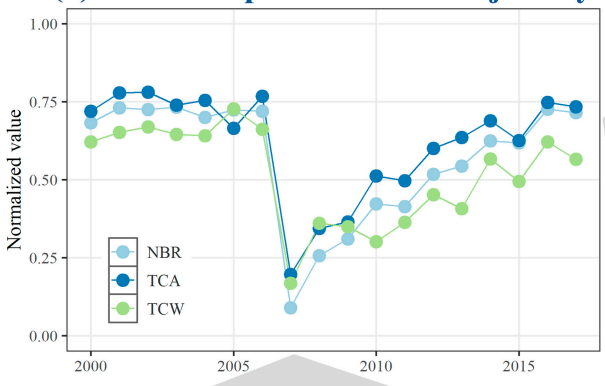

(b) Landsat time series

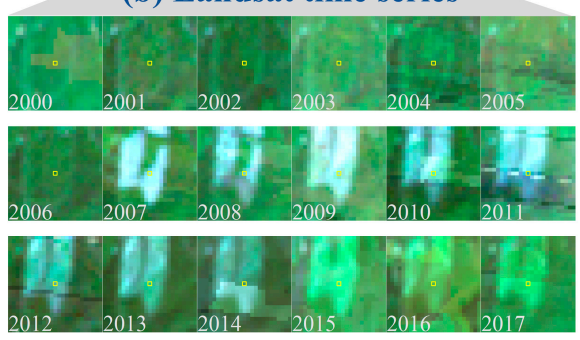

(c) Google Earth
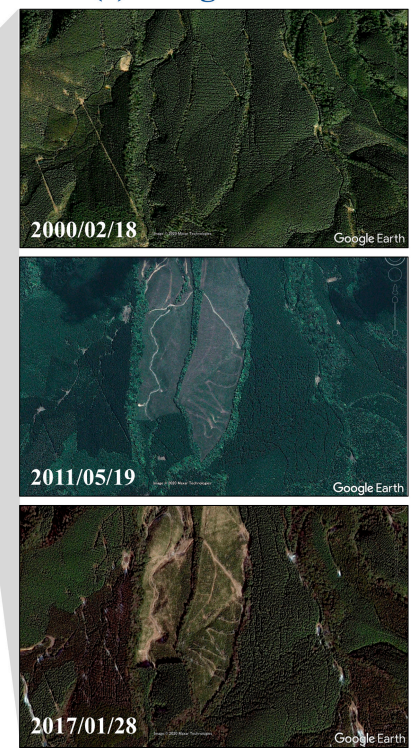

Figure 2. Schematic example of the visual interpretation for a pixel-based sample using the (a) trajectory of the spectral indices of the Landsat time-series data, (b) RGB images of the Landsat time-series data, and (c) high-resolution satellite images from Google Earth (images (C) 2020 Maxar Technologies).

\subsubsection{Sample Grid Reference Data for 2013-2017 at a $10 \mathrm{~m}$ Spatial Resolution}

To assess the accuracy of annual disturbance detection and use in mixed-effect models, the sample grid reference data was collected using $6 \times 6 \mathrm{~km}$ grids at a $10 \mathrm{~m}$ spatial resolution. The accuracy assessment using the sample data in grids and blocks was widely implemented in previous studies (e.g., [66-68]). In this study, the study area was first divided into $6 \times 6 \mathrm{~km}$ grids, resulting in 1408 grids that overlapped with the land area. The cumulative disturbance area of the local disturbance map from 2013 to 2017 was calculated in each grid. Then, a total of 35 grids that overlapped with more than 
$20 \%$ of the land area were randomly selected from the four strata corresponding to the disturbance area ratios of $0 \%, 0-1 \%, 1-3 \%$, and $>3 \%$ (i.e., $10,10,8$, and 7 grids, respectively).

All annual forest disturbances from 2013 to 2017 in the selected grids were manually delineated using Sentinel-2 composite images (Figure 3). Because no Sentinel-2 data was available before Sentinel-2A was launched in 2015, the forest disturbances from 2013 to 2015 were delineated using the Sentinel-2 composite images in 2016. Then, the timing of each forest disturbance was attributed using Landsat images. We assumed that this procedure rarely caused a disturbance omission because the forest disturbances in this region were visible from the satellite images for several years after the disturbance events. Manually delineated disturbances were confirmed using high-resolution satellite images in Google Earth. The Automated Registration and Orthorectification Package (AROP) [69] was used in each grid to reduce the miss registration between the disturbance detection based on the Landsat images and the reference data based on the Sentinel-2 images. The near-infrared band of the Landsat and Sentinel-2 composite images was used to align the Sentinel-2 images to the Landsat images in the AROP. The delineated results were rasterized to a $10 \mathrm{~m}$ spatial resolution. Water surfaces, such as rivers and seas, were masked in the reference data. The total valid area in the 35 reference grids accounted for $2.9 \%$ of the study area.

\subsection{Accuracy Assessments of Disturbance Detection for the Entire Study Area}

The area-based thematic accuracies of both the Global Forest Change map and local disturbance map were assessed based on two reference data. For the accuracy assessment using the $10 \mathrm{~m}$ spatial resolution grid reference data of 2013-2017, both maps were resampled to a $10 \mathrm{~m}$ spatial resolution using the nearest neighbor method to evaluate the effects of the mixed pixels. All pixels in both reference data were used for the calculation. The producer's accuracy (PA) and the user's accuracy (UA) of the forest disturbance were calculated as follows using the ratio estimator [65,70]:

$$
\hat{R}=\frac{\sum_{h=1}^{H} N_{h} \bar{y}_{h}}{\sum_{h=1}^{H} N_{h} \bar{x}_{h}}
$$

where $H$ is the number of strata, $N_{h}$ is the total number of pixels in the stratum $h, \bar{y}_{h}$ and $\bar{x}_{h}$ are the sample means of $y_{u}$ and $x_{u}$, respectively, at the stratum $h$, and $y_{u}$ and $x_{u}$ are the numerator and the dominator in the equation defined for each accuracy metrics using pixel $u$, respectively [71]. The variance of $\hat{R}$ was calculated as follows:

$$
\hat{V}(\hat{R})=\frac{1}{\hat{X}^{2}} \sum_{h=1}^{H} N_{h}^{2}\left(1-\frac{n_{h}}{N_{h}}\right)\left(s_{y h}^{2}+\hat{R}^{2} s_{x h}^{2}-2 \hat{R} s_{x y h}\right) / n_{h}
$$

where $n_{h}$ is the number of sample pixels in the stratum $h, s_{y h}^{2}$ and $s_{x h}^{2}$ are the sample variances of $y_{u}$ and $x_{u}$ in the stratum $h$, respectively, and $\hat{X}$ and $s_{x y h}$ are defined as follows:

$$
\begin{gathered}
\hat{X}=\sum_{h=1}^{H} N_{h} \bar{x}_{h} \\
s_{x y h}=\sum_{u=1}^{n_{h}}\left(y_{u}-\bar{y}_{h}\right)\left(x_{u}-\bar{x}_{h}\right) /\left(n_{h}-1\right)
\end{gathered}
$$

An approach in Stehman [65] was used to calculate the error matrices, other accuracy metrics, and area estimates. When assessing the accuracy of both maps, the temporal difference of 1 year was allowed for the correct disturbance detection because the date of the satellite data acquisition might cause a difference in the detection year. In addition, the map accuracy for the entire study period was calculated using the same approach. 

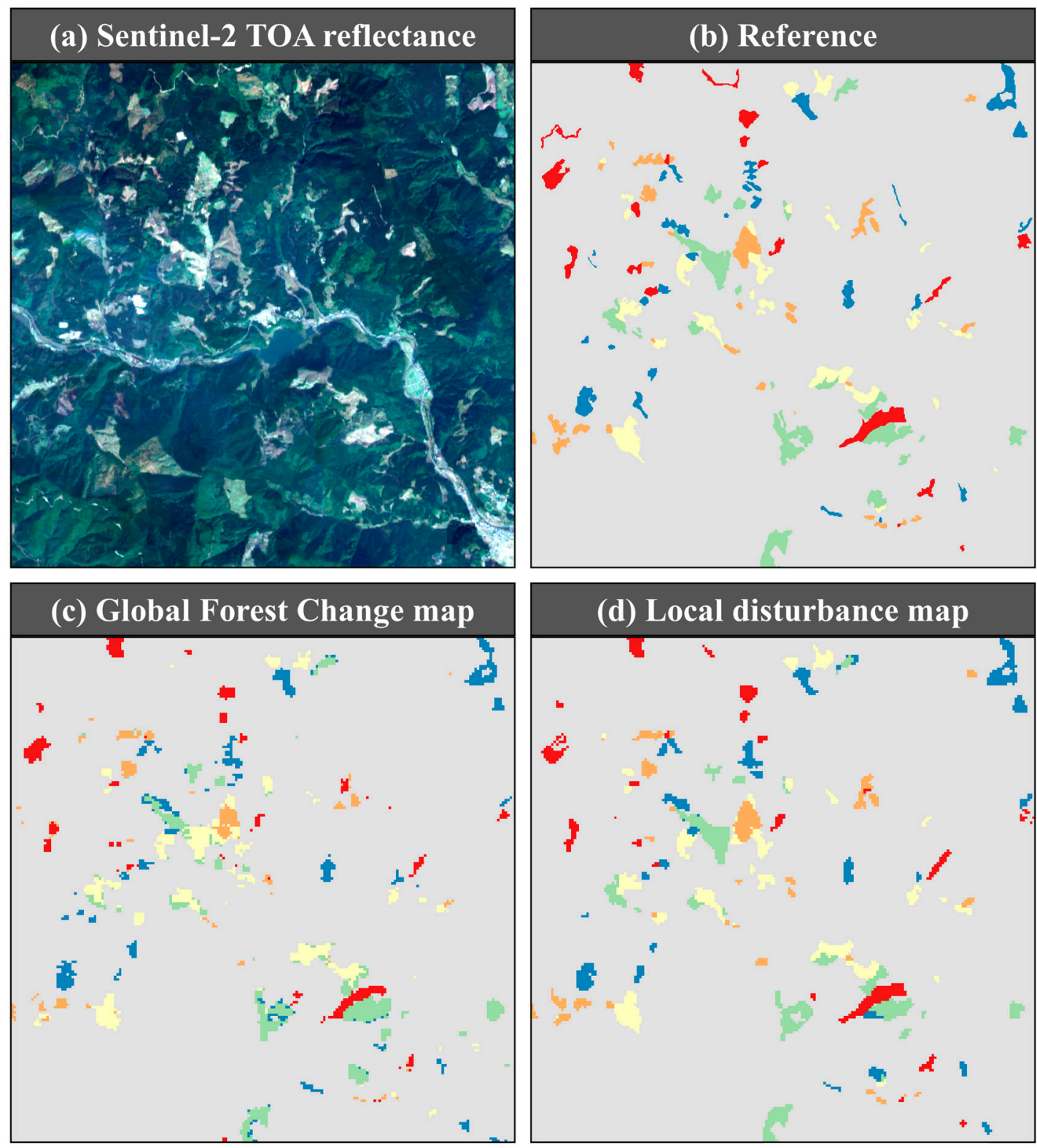

(d) Local disturbance map
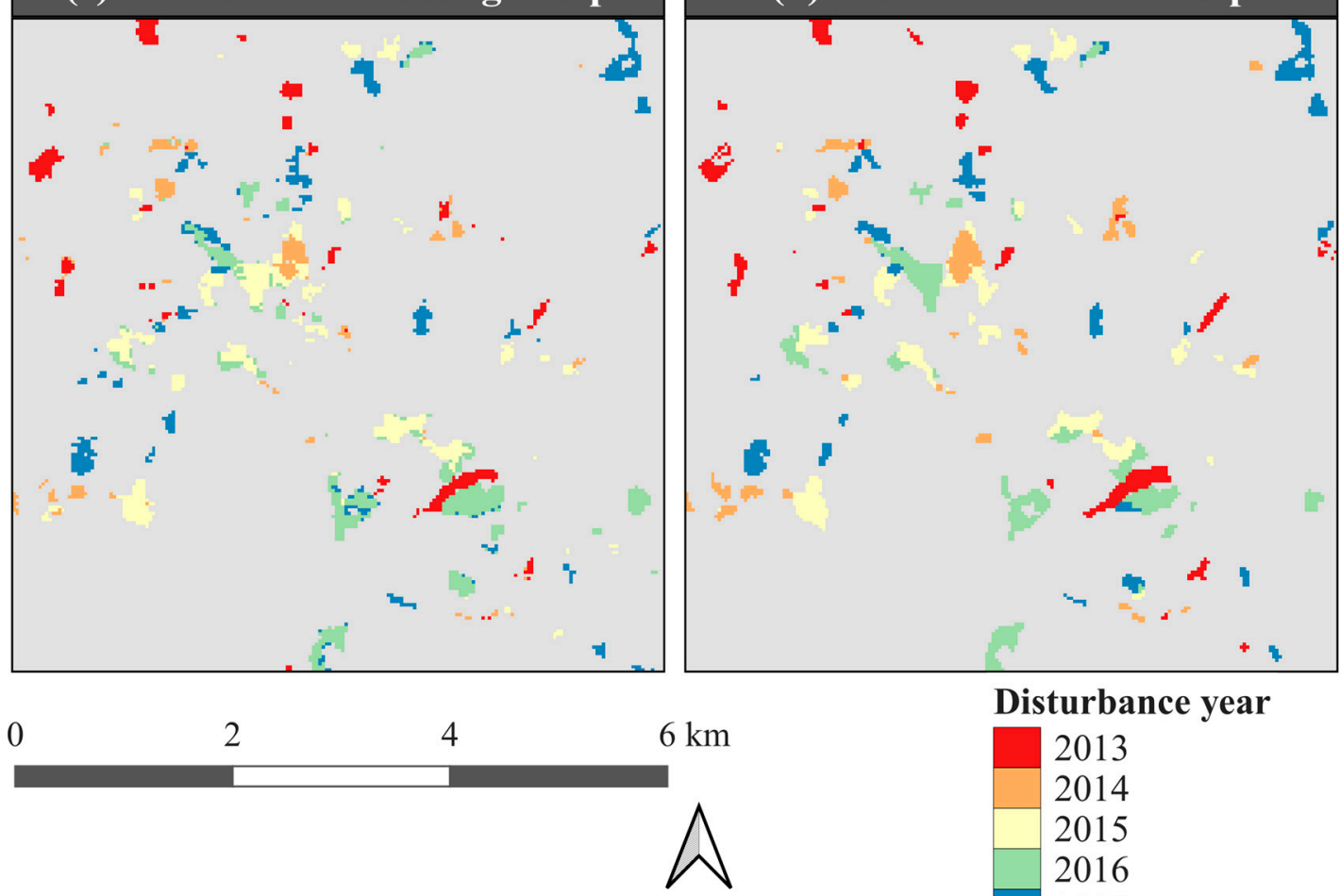

Disturbance year

2013

2014

2015

2016

2017

Figure 3. Visualization of the forest disturbances in a selected $6 \times 6 \mathrm{~km}$ grid; (a) Sentinel-2 top of atmosphere (TOA) reflectance composite image in 2018; (b) manually delineated reference data; (c) Global Forest Change map; (d) local disturbance map.

\subsection{Polygon-Based Accuracy Assessment}

Similar to that in the study of Linke et al. [54], the polygon-based assessment was implemented herein to calculate a polygon-based thematic accuracy using the 35-grid reference data. Both the Global Forest Change map and the local disturbance map were resampled to a $10 \mathrm{~m}$ spatial resolution using the nearest neighbor method. The spatial overlap proportion at each reference and the detected disturbance patch were used to identify the correct detection. Each reference disturbance patch was assessed as regards whether the spatial overlap proportion with the detected disturbance in the Global 
Forest Change or local disturbance map was larger than the threshold, and vice versa. The thresholds for the spatial overlap proportion from $0 \%$ to $100 \%$ were then investigated. The higher thresholds indicate a stricter assessment for identifying the correct disturbance, whereas the lower thresholds denote a relaxed assessment. We calculated the pseudo-PA, which is the number of correctly detected disturbance patches divided by the total number of reference disturbance patches, and the UA, which is the number of correctly detected disturbance patches divided by total number of detected disturbance patches, for both maps. We also evaluated the pseudo-PA and the UA at different disturbance size classes using the spatial overlap threshold of $50 \%$, following the approach of Linke et al. [54]. The disturbance patches located at the edge of each grid were removed to avoid the effects of the disturbance that occurred outside the grids.

\subsection{Mixed-Effect Modeling}

A Generalized Linear Mixed Model (GLMM) with a logit link and a binomial family was used based on the variables derived from the $10 \mathrm{~m}$ reference grid data to investigate the influencing factors of the correct disturbance detection. A total of $10 \%$ of disturbance pixels in the reference data were randomly selected as the GLMM input. The response variable was "correctly detected" or "not detected" by the Global Forest Change map and local disturbance map in each year. The explanatory variables were the pre-NBR value (i.e., NBR value in the previous year), delta NBR value (i.e., the difference of the NBR value from the previous year), topographic elevation, slope, disturbance patch size of the disturbance, and distance from the disturbance edge. Each disturbance patch was used as a random effect following a similar approach by Gibson et al. [72]. The explanatory variables were calculated at a $10 \mathrm{~m}$ spatial resolution. The explanatory variables were selected by a step-wise elimination based on the Akaike Information Criterion (AIC). The "glmmML" package was used to implement the GLMM in R statistical software [73].

\section{Results}

\subsection{Accuracy Assessment Using Pixel-based Reference Data in 2001-2017}

Figure 4 shows the PAs and the UAs of the disturbance in the accuracy assessment based on the pixel-based reference data at a $30 \mathrm{~m}$ spatial resolution from 2001-2017 (the reader is advised to see the error matrices provided in the supplementary tables for details). The PAs and the UAs of the disturbance of the Global Forest Change map varied for each year and ranged from $30.7 \%$ to $76.8 \%$ and $50.6 \%$ to $90.2 \%$, respectively, whereas those for the local disturbance map were $78.3-92.5 \%$ and $88.8-97.1 \%$, respectively. Large differences were also found in the Global Forest Change map across the years. The PA and the UA of the disturbance for the entire period of 2001-2017 were $62.4 \%$ (95\% confidence interval of $\pm 6.6 \%)$ and $65.5 \%( \pm 10.1 \%)$, respectively, for the Global Forest Change map and $87.4 \%( \pm 7.5 \%)$ and $94.1 \%( \pm 2.4 \%)$, respectively, for the local disturbance map.

Figure 5 summarizes the disturbance area estimated from the Global Forest Change map, local disturbance map, and reference data. The disturbance areas of both maps were calculated from a pixel-counting approach in the study area. The total disturbance area estimated in the reference data accounted for $3.2 \%$ of the study area in the entire study period (i.e., $0.2 \%$ annual average).

\subsection{Accuracy Assessment Using the Sample Grid Reference Data for 2013-2017}

Figure 6 shows the PAs and the UAs of the disturbance in the accuracy assessment based on the grid reference data at a $10 \mathrm{~m}$ spatial resolution for 2013-2017 (the reader is advised to see the error matrices provided in the supplementary tables for details). The Global Forest Change map achieved PAs and UAs of 53.2-69.3\% and 65.5-80.3\%, respectively (Figure 6), while the local disturbance map achieved PAs and UAs of $65.4-78.6 \%$ and $75.0-82.4 \%$, respectively. The PA and UA of the disturbance for the entire period of $2013-2017$ were $62.2 \%( \pm 0.3 \%)$ and $71.8 \%( \pm 0.3 \%)$, respectively, for the Global Forest Change map and $72.5 \%( \pm 0.2 \%)$ and $78.9 \%( \pm 0.2 \%)$, respectively, for the local disturbance map. 


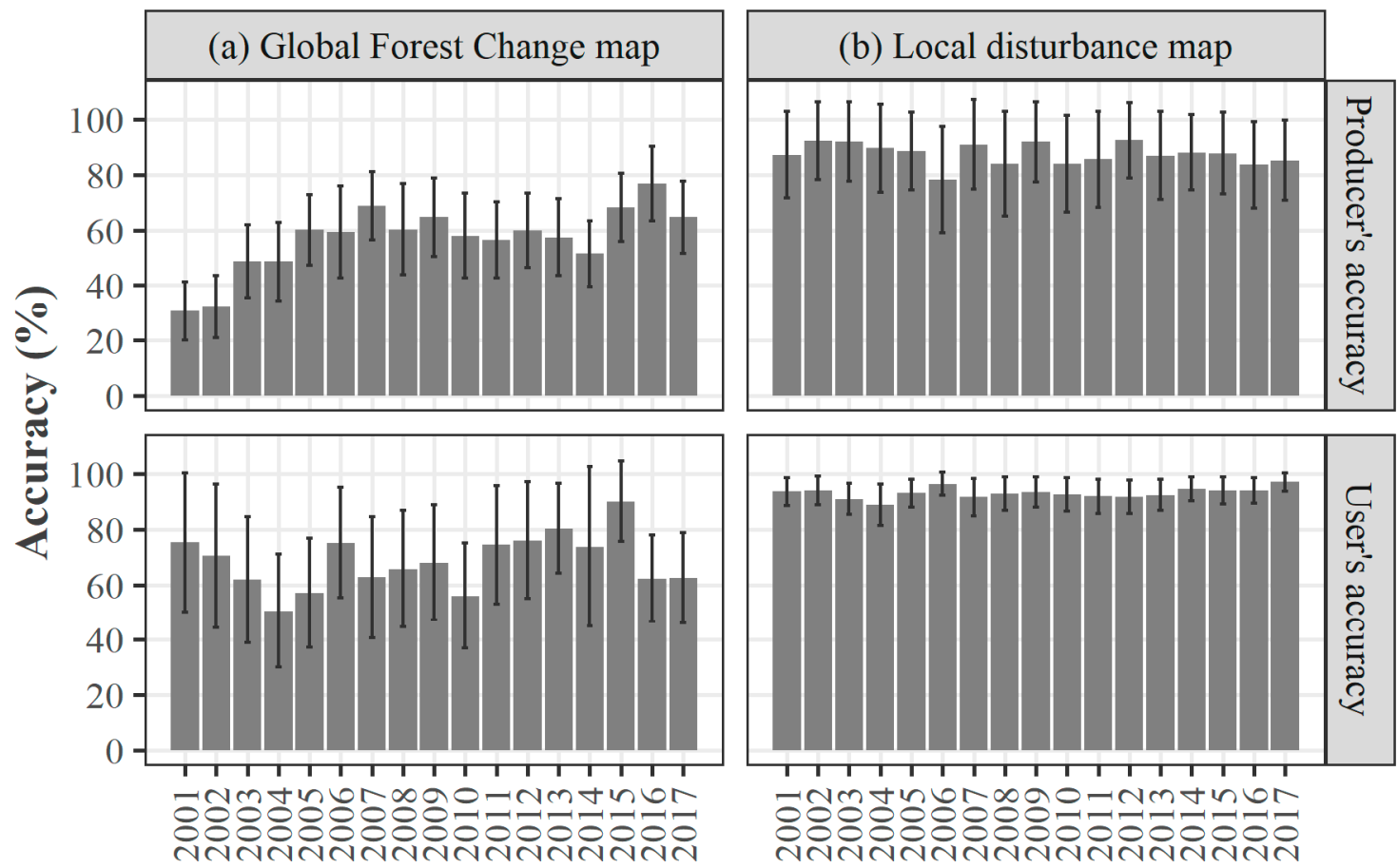

Figure 4. Producer's accuracy (PA) and user's accuracy (UA) of the disturbance in the (a) Global Forest Change map and (b) local disturbance map in each year at a $30 \mathrm{~m}$ spatial resolution. The error bars represent the $95 \%$ confidence interval.

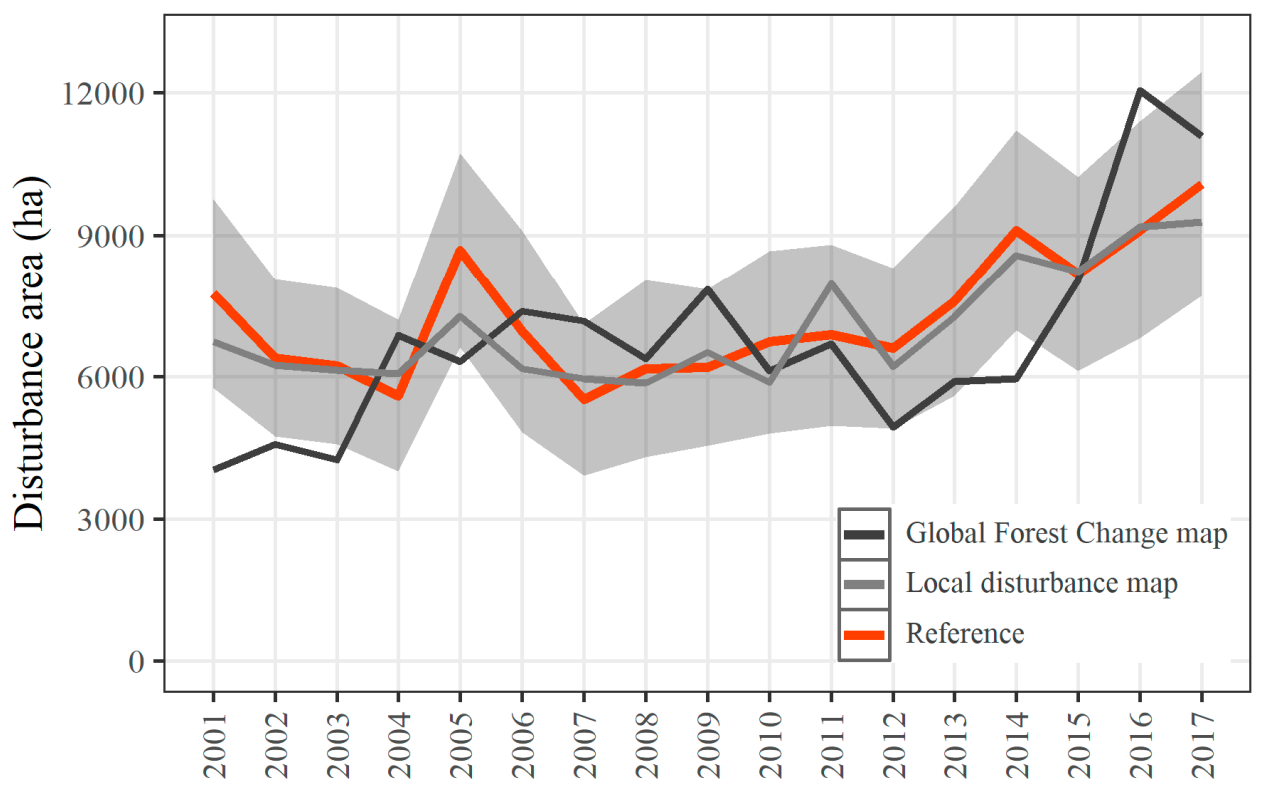

Figure 5. Disturbance area in each year from the Global Forest Change map, local disturbance map, and reference data. The dark gray area indicates the $95 \%$ confidence interval.

\subsection{Polygon-based Assessment of Disturbance Detection in 2013-2017}

Figure 7 depicts the distribution of the disturbance patch size in the reference sample grids. The total numbers of disturbance patches in the reference sample grids in the Global Forest Change map, local disturbance map, and reference data were 2067 (1699.5 ha), 1167 (1773.5 ha), and 1233 (1851.6 ha), respectively. The average and median disturbance patch sizes of the reference data were 1.50 ha and 0.75 ha, respectively. The number of disturbance patches of less than 1 ha accounted 
for $60.7 \%$ of the total disturbance patches in the reference data. On the other hand, the total area of disturbance of less than 1 ha accounted for $19.2 \%$ of the total disturbance area.
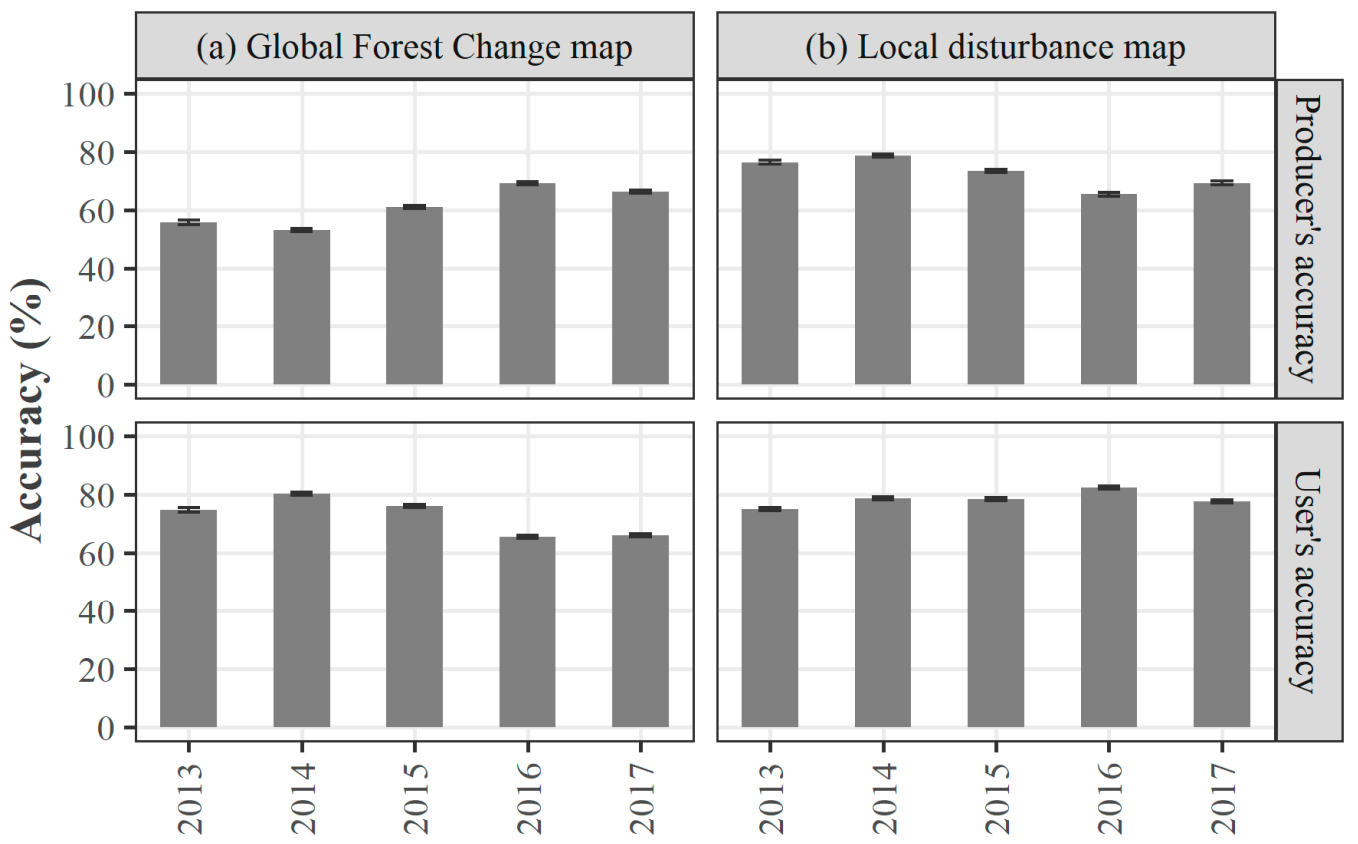

Figure 6. PA and UA of the disturbance in the (a) Global Forest Change map and (b) local disturbance map in each year at a $10 \mathrm{~m}$ spatial resolution. The error bars represent the $95 \%$ confidence interval.

The pseudo-PAs and UAs of the disturbance decreased with the higher spatial overlap thresholds (Figure 8a). The PAs of all the disturbance sizes of the Global Forest Change map at $0 \%$ threshold were larger than those of the local disturbance map. However, for thresholds larger than or equal to $20 \%$, the local disturbance map achieved higher PAs than the Global Forest Change map. The UAs of the local disturbance map were consistently larger than those of the Global Forest Change map at the spatial overlap thresholds of $0-90 \%$. The PA and UA of the Global Forest Change map at the spatial overlap thresholds of $0 \%, 20 \%$, and $50 \%$ were $86.0 \% / 77.4 \%, 76.1 \% / 73.2 \%$, and $54.1 \% / 58.5 \%$, respectively, while those of the local disturbance map were $77.3 \% / 96.0 \%, 76.4 \% / 95.4 \%$, and $67.2 \% / 87.2 \%$, respectively. When divided into a disturbance size larger than or equal to 1 ha (Figure 8b) and less than 1 ha (Figure 8c), the PAs and UAs of the disturbance larger than or equal to 1 ha were generally higher than those of less than 1 ha. For a disturbance larger than or equal to 1 ha, the UAs of both disturbance maps were almost the same at the thresholds $0-50 \%$ with differences of less than $4 \%$. The PAs were generally smaller in the Global Forest Change map than in the local disturbance map. The PA and UA of the Global Forest Change map at the spatial overlap thresholds of 0\%, 20\%, and 50\% were 94.7\%/98.9\%, $88.1 \% / 98.7 \%$, and $73.9 \% / 92.8 \%$, respectively, for a disturbance larger than or equal to 1 ha, while those for the local disturbance map were $97.5 \% / 98.9 \%, 96.5 \% / 98.7 \%$, and $86.0 \% / 97.1 \%$, respectively. For a disturbance of less than 1 ha, the PAs of the disturbance at thresholds lower than $30 \%$ were higher in the Global Forest Change map, indicating that the disturbance was more likely detected by this map. The PA and UA of the Global Forest Change map at the spatial overlap thresholds of $0 \%, 20 \%$, and $50 \%$ were $80.3 \% / 72.4 \%, 68.2 \% / 67.4 \%$, and $41.1 \% / 50.6 \%$, respectively, while those for the local disturbance map were $64.1 \% / 94.1 \%, 63.3 \% / 93.3 \%$, and $55.0 \% / 81.0 \%$, respectively, for a disturbance smaller than 1 ha. 


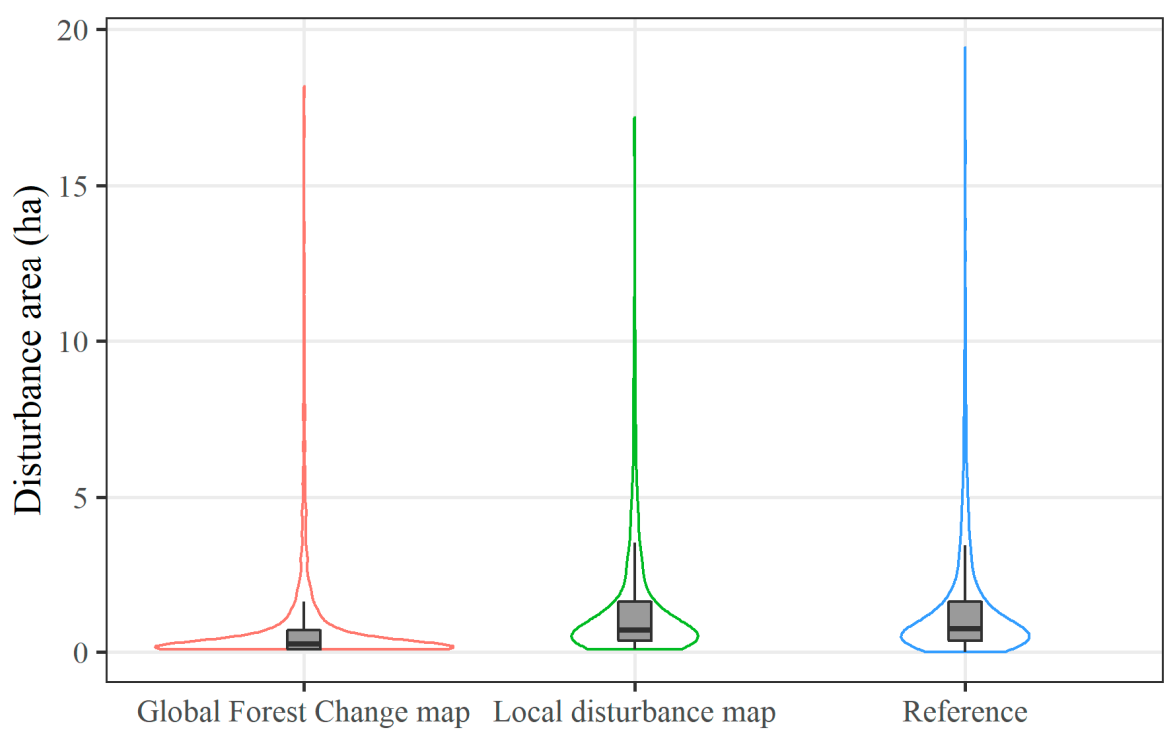

Figure 7. Distribution of the disturbance patch size in the Global Forest Change map, local disturbance map, and reference data. The disturbance patch size was calculated based on each year.
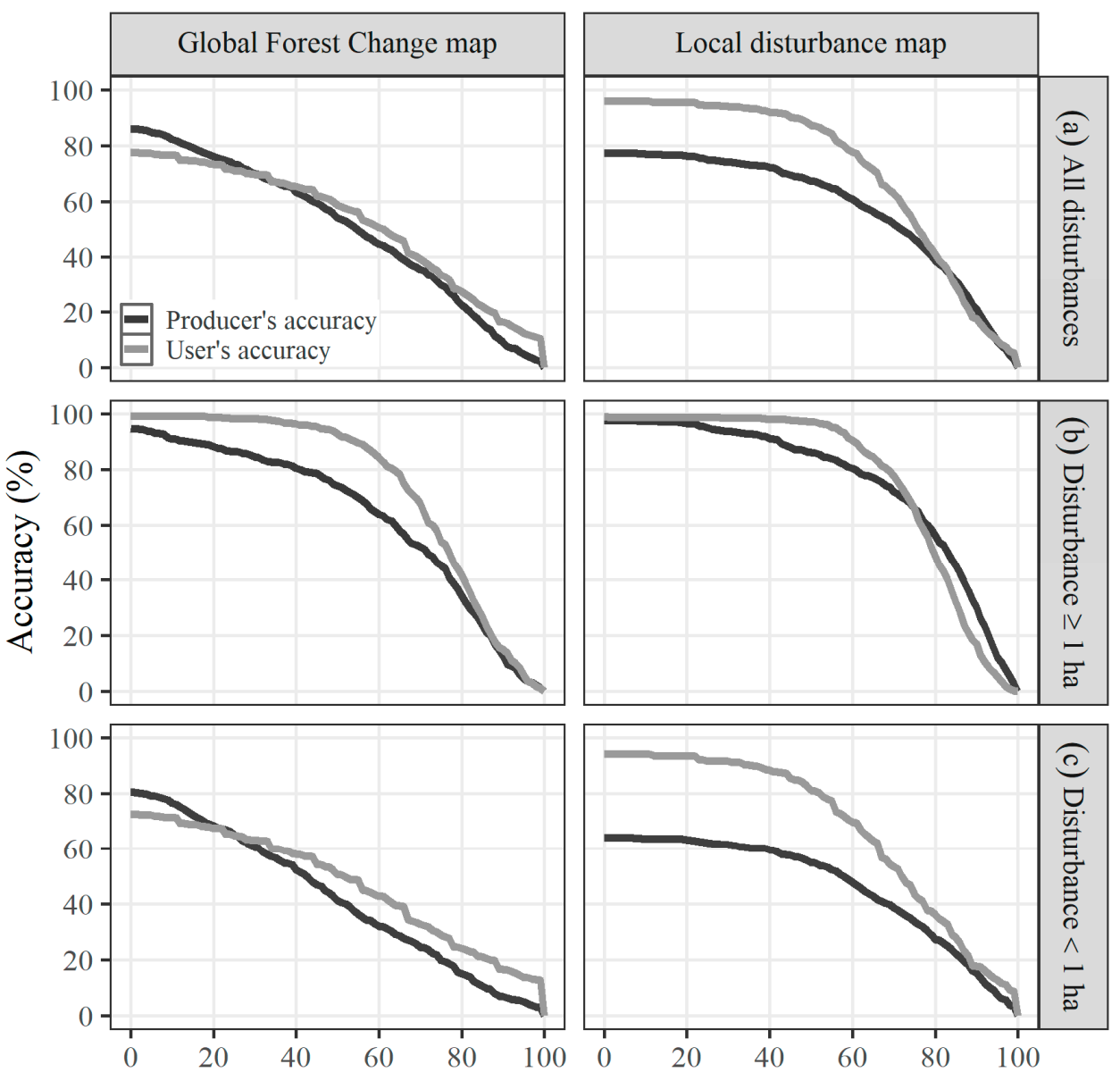

Spatial overlap threshold (\%)

Figure 8. PA and UA of the disturbance at each spatial overlap threshold in the polygon-based assessment: (a) all disturbances, (b) disturbance larger than or equal to $1 \mathrm{ha}$, and (c) disturbance of less than 1 ha. 
The pseudo-PAs and UAs using the overlap threshold of 50\% increased with the increasing disturbance size class (Figure 9). The PAs and UAs of the local disturbance map were higher than or equal to those of the Global Forest Change map. The PAs of the Global Forest Change map and the local disturbance map for the disturbance size class of $0-0.5$ ha were $34.4 \%$ and $40.9 \%$, respectively. The PA and the UA exceeded $80 \%$ for a disturbance larger than 3 ha in the Global Forest Change map and larger than 1 ha in the local disturbance map.

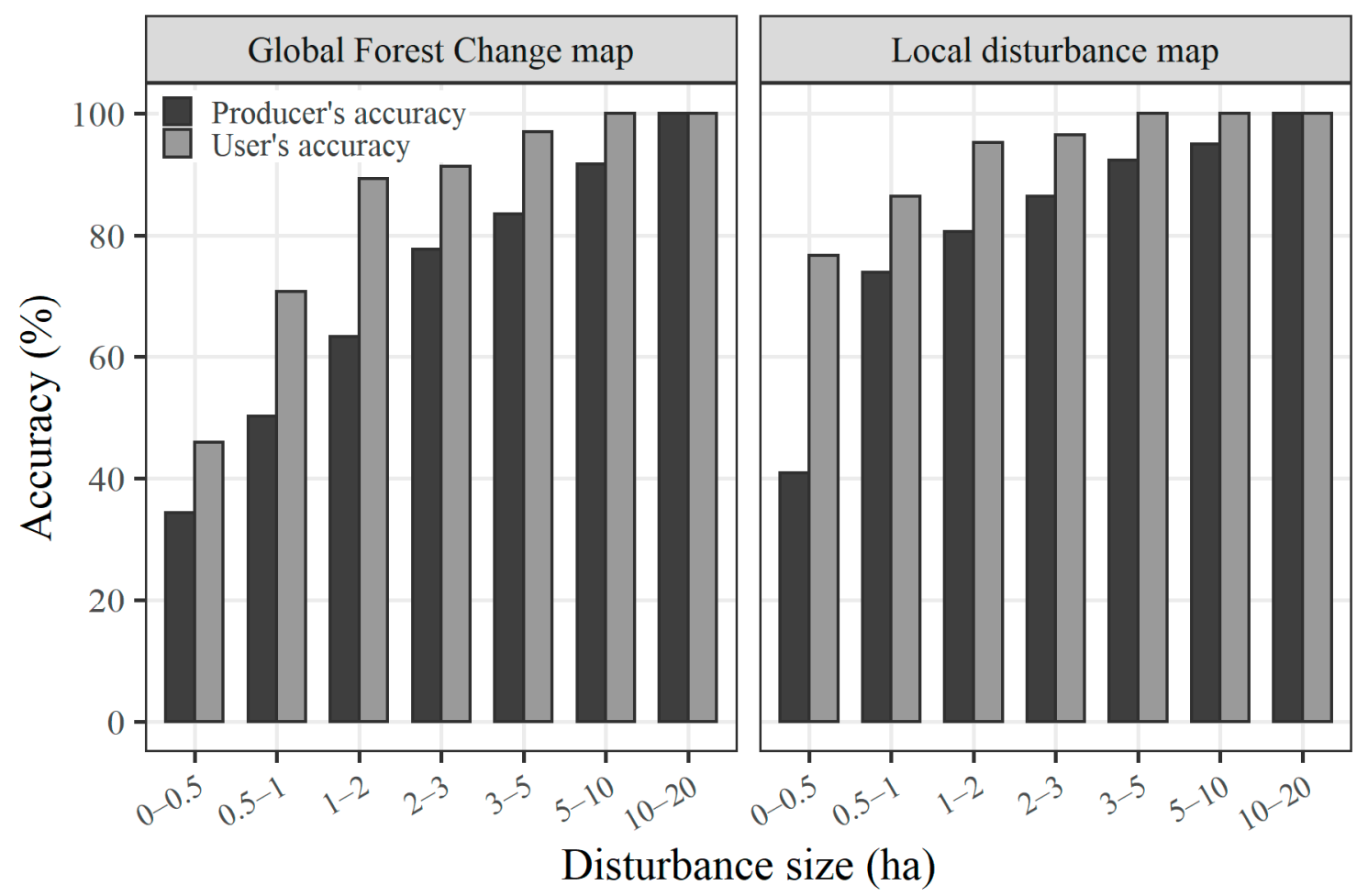

Figure 9. PA and UA of the disturbance at each disturbance patch size class for the Global Forest Change map and the local disturbance map in the polygon-based assessment using a 50\% overlap threshold.

\subsection{GLMM}

The GLMM results showed that the pre-NBR value, delta NBR value, disturbance patch size, and distance from the disturbance edge were significant explanatory variables in both maps (Table 1). A larger disturbance patch size and the distance from the disturbance edge were related to a higher correct detection, whereas higher pre-NBR and delta NBR values were associated with a lower correct detection. Figure 10 shows the distribution of each variable for the correct detection and the omission of the disturbance pixels. Figure 11 illustrates the disturbance and no-disturbance detection rate for the distance from the disturbance edge. Inside the reference disturbance patches, the correct detection rate increased with increasing distance from the disturbance edge until $120 \mathrm{~m}$. The correct detection rate became larger than $90 \%$ at distances of 40 and $70 \mathrm{~m}$ for local and Global Forest Change maps, respectively. Outside the reference disturbance patches, the correct detection rate became larger than $90 \%$ at a distance of $30 \mathrm{~m}$ in both disturbance maps. 
Table 1. Result of the Generalized Linear Mixed Model (GLMM) for the disturbance detection of the (a) Global Forest Change map and the (b) local disturbance map.

\begin{tabular}{ccccc}
\hline Model & Variables (Fixed Effects) & Estimate & Std. Error & z Value \\
\hline (a) Global Forest & (Intercept) & -1.737 & 0.195 & -8.897 \\
Change map & Pre-NBR & -1.981 & 0.270 & -7.325 \\
& $\begin{array}{c}\text { Delta NBR } \\
\text { Distance from }\end{array}$ & -8.391 & 0.152 & -55.103 \\
& $\begin{array}{c}\text { disturbance edge } \\
\text { (b) Local }\end{array}$ & 0.032 & 0.001 & 22.373 \\
disturbance map & Disturbance patch size & 0.124 & 0.027 & 4.507 \\
& (Intercept) & -4.540 & 0.273 & -16.612 \\
& $\quad \begin{array}{c}\text { Pre-NBR } \\
\text { Delta NBR }\end{array}$ & -2.138 & 0.375 & -5.703 \\
& $\begin{array}{c}\text { Distance from } \\
\text { disturbance edge }\end{array}$ & 0.029 & 0.385 & -65.753 \\
& Disturbance patch size & 0.235 & 0.036 & 12.918 \\
\hline
\end{tabular}
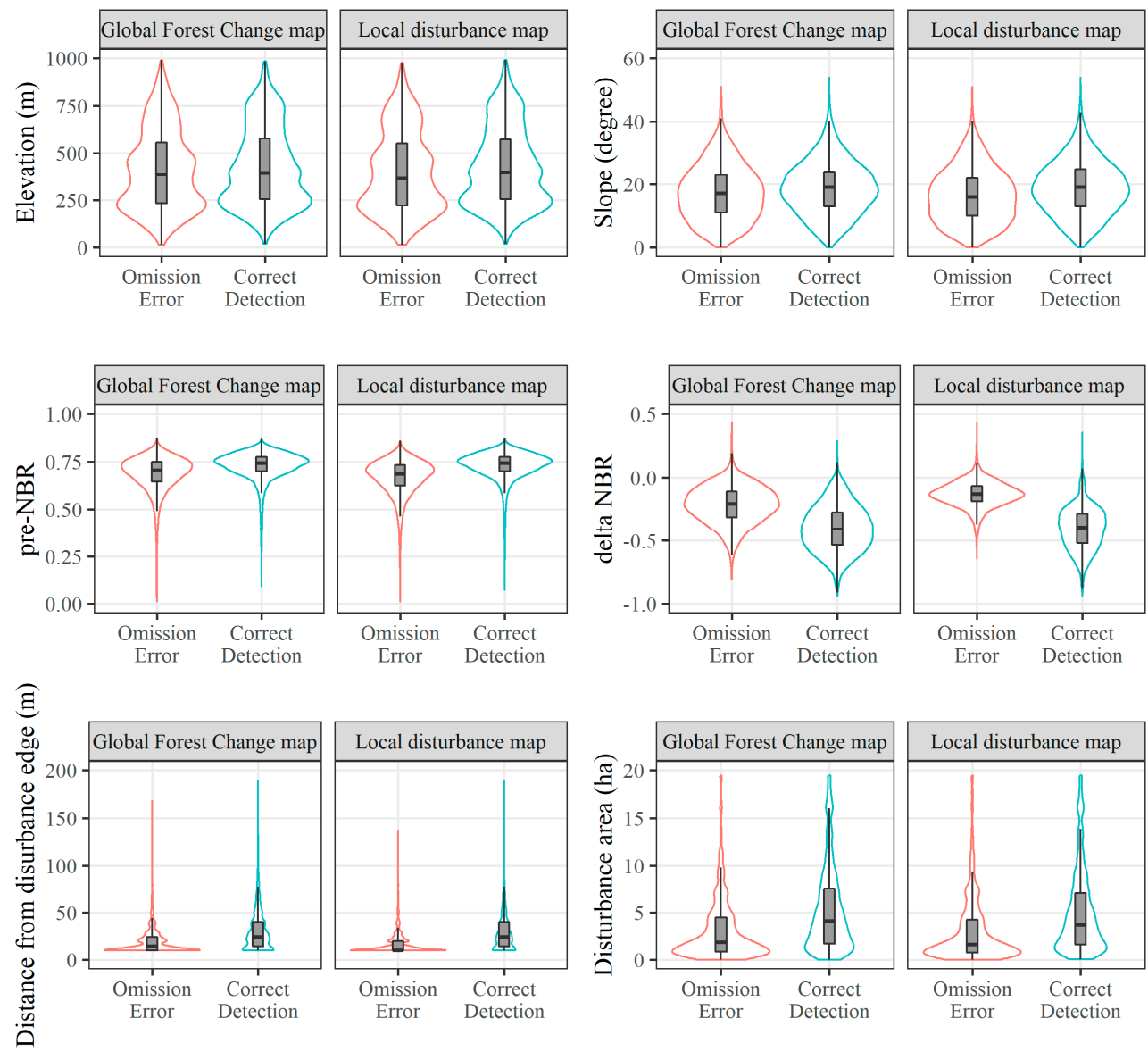

Figure 10. Violin plots of the distribution of the variables investigated in the GLMM. 


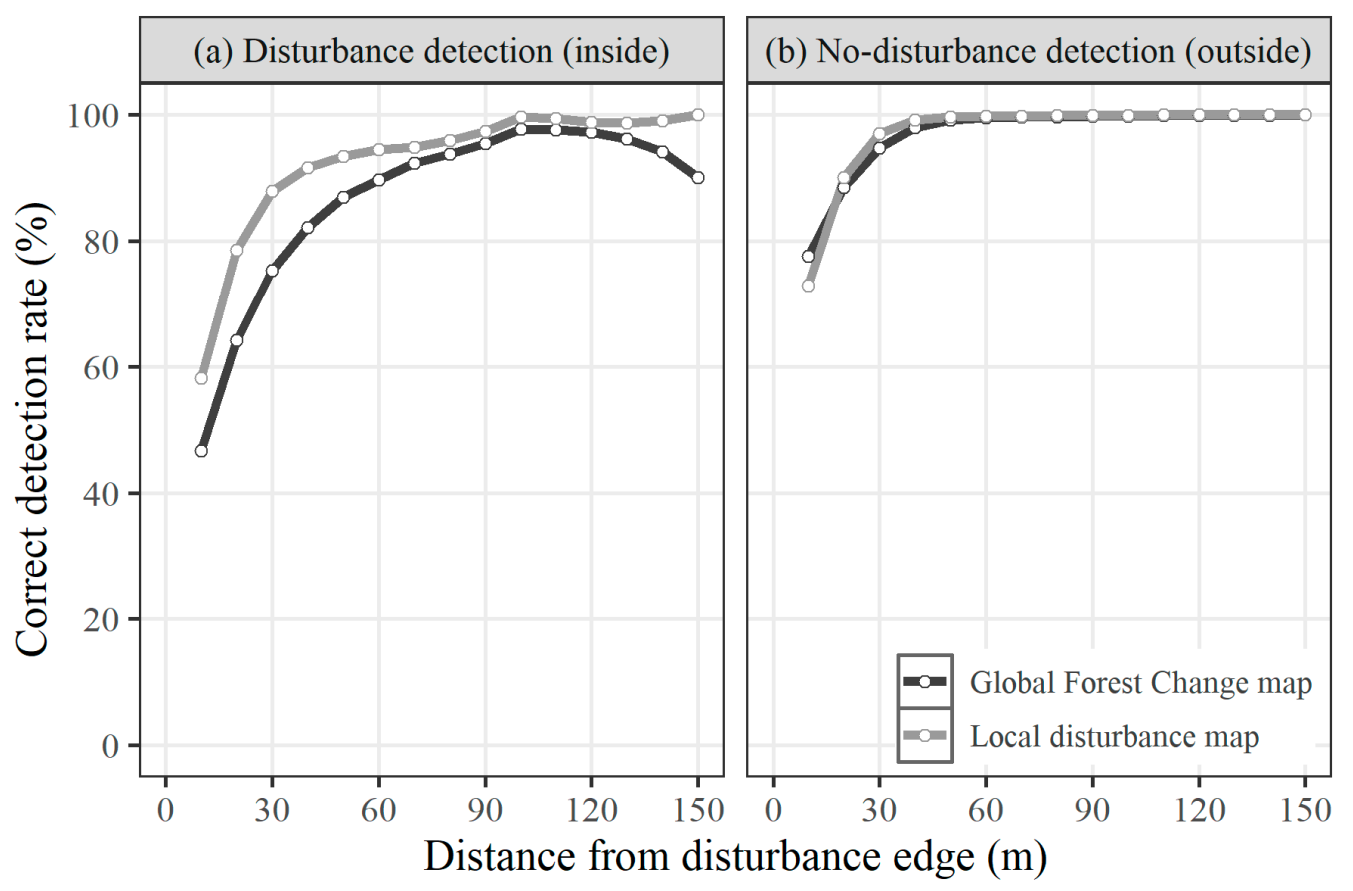

Figure 11. Correct detection rate for the (a) disturbance detection and (b) no-disturbance detection at each distance from the disturbance edge. The disturbance was binned with a 10-m bin width.

\section{Discussion}

The choice of the Global Forest Change map or the local disturbance map for estimating forest disturbances depends on the trade-offs between the accuracy and the usability of these disturbance maps. The accuracy of the annual disturbance detection provides an insight into the trade-offs and efficient use of disturbance maps. This study assessed the annual disturbance detection by investigating the detection accuracy in the entire study area, polygon-based accuracy, and influencing factors for correct detection. These detailed assessments provided complementary information to determine the possible use of different disturbance maps to estimate the annual forest disturbances.

The accuracies of the annual disturbance detection were higher in the local disturbance map than in the Global Forest Change map in both reference data. The detected disturbance area and the estimated accuracy in the Global Forest Change map considerably differed for 2001-2017. This result is in line with the findings of previous studies that indicated the differences in accuracy and estimated area in different years $[43,46]$. The better performance of the local disturbance map is not surprising because the local disturbance map used in this study was based on the LandTrendr segmentation, which enhanced the temporal information, and was calibrated to this study area. This indicates that developing a local disturbance map in the study area is a simple approach for improving the disturbance detection accuracy. However, a previous study showed that the disturbance detection accuracy using the local and Global Forest Change maps varied regionally [46]. This might be because the disturbance detection accuracy is affected by climatic and vegetation factors, such as satellite data availability due to clouds and vegetation recovery after disturbances. Furthermore, the accuracy of the local disturbance map is affected by change detection algorithms. Cohen et al. [74] demonstrated that the detection results were largely different in each detection algorithm. In this context, change detection algorithms should be suitable for the study area in terms of regional disturbance processes and data availability. The integration of several algorithms using ensemble learning (e.g., [75,76]) is one possible solution for minimizing the influences of algorithm selection.

The accuracy metrics calculated using pixel-based and sample grid reference data were largely different from each other in both disturbance maps in the 2013-2017 period. The accuracy metrics based on the pixel-based reference data generally had higher accuracies (Figures 4 and 6) that can be attributed 
to the different spatial resolutions of the two reference data (i.e., 10 and $30 \mathrm{~m}$ ). Both disturbance maps were originally developed at a $30 \mathrm{~m}$ spatial resolution; hence, the mixed pixels containing the disturbance boundaries were assessed in the validation using the reference data with the $10 \mathrm{~m}$ spatial resolution, but not in reference data with the $30 \mathrm{~m}$ spatial resolution. The differences can be substantial for small-scale disturbances because of the lower correct detection rate near the edge of the disturbances (Figure 11). In areas dominated by small-scale disturbances, such as those in this study, these differences largely affect the accuracy metrics of the entire study area. In addition, the pixel-based reference data collected with stratified random sampling in the local disturbance map might reduce the inclusion of small-scale disturbances. This can lead to optimistically estimated accuracies because disturbances of less than four pixels were removed from the local disturbance map. Note that the reference data collected at the $10 \mathrm{~m}$ spatial resolution might be influenced by the image registration error between Landsat and Sentinel-2 and the miss delineation of the disturbance shapes in the visual interpretation process. A further rigorous accuracy assessment for the mixed pixels should be conducted using high-resolution satellite images or other remote sensing data, such as aerial photographs.

The polygon-based assessment revealed that the Global Forest Change map can detect disturbances at least partially, even though the commission error was also high. The PAs of the disturbances of less than 1 ha in the local disturbance map were lower than those of the Global Forest Change map in lower spatial overlap thresholds because disturbance patches of less than four pixels were removed to reduce the commission error in the local disturbance map. However, if the 50\% spatial overlap is required for correct detection, the local disturbance map has better accuracies even for small-scale disturbances. The PA and UA of the disturbance exceeded 80\% for the disturbance larger than 3 ha in the Global Forest Change data and that larger than 1 ha in the local disturbance map. These results indicate that both disturbance maps can feasibly detect larger disturbances at a 50\% spatial overlap. If the UA of $80 \%$ is sufficient to reduce false change detection, both maps can be used to detect disturbances larger than 1 ha and 0.5 ha, respectively. The difficulty of detecting small-scale disturbances ranging from 1 to 3 ha was addressed in previous studies [42,45,54]. Although the polygon-based assessment did not depend on the entire study area but rather on the sample grid reference data, we assumed that the estimates had little bias because the total area of the sample grids was large and accounted for $2.9 \%$ of the entire study area.

The delta NBR, pre-NBR, disturbance patch size, and distance from the disturbance edge were the significant factors influencing the disturbance detection. The delta NBR represents the difference in the vegetation condition of two consecutive years; hence, selecting it as a significant explanatory variable for disturbance detection was not surprising and confirmed the findings of the previous studies (e.g., [56,77]). The disturbance patch size also affected the detection accuracy in the various types of disturbance in previous studies (e.g., [55]). This might be indirectly affected by the mixed pixels in near-disturbance edges. Previous studies investigated the possible effects by adjacent pixels in MODIS at a $500 \mathrm{~m}$ resolution [78] and used the omission error near the disturbance edge for the accuracy assessment (e.g., [79]). The present study confirmed the relationship of the omission error at a finer spatial resolution of $30 \mathrm{~m}$. Although Hamunyela et al. [44] indicated that elevation is an influencing factor for disturbance detection in the Global Forest Change map in Tanzania, this was not confirmed herein. This discrepancy might have been affected by several factors, such as regional data availability, cloud cover condition, elevation range, and vegetation. Although the results of this study did not confirm, these factors should be considered when using disturbance maps in such regions. Disturbance agents, such as fire, windthrow, and harvesting, can affect the detection accuracy because different disturbance agents have different disturbance sizes, vegetation recovery conditions, and magnitudes of change $[13,22]$. These factors should be analyzed to assess possible errors in regions with various disturbance agents.

The local disturbance map can be generated using satellite data with more frequent steps or a higher spatial resolution (e.g., Sentinel-2 data). Note that in this study, the pixel size of the Landsat data for detecting small-scale disturbances was coarse, and this might be alleviated by using 
high-spatial-resolution data. The use and integration of local disturbance maps using other satellite data should be investigated in different regions.

\section{Conclusions}

This study investigated the accuracy of annual disturbance detection using the Hansen Global Forest Change map and the local disturbance map in temperate forests dominated by harvest related disturbances. The local disturbance map generally achieved higher and more stable accuracies in each year compared with the Global Forest Change map. Therefore, the generation of a locally calibrated map is a valid approach if higher accuracy is required. The accuracy assessments revealed that the accuracies and the detected disturbance areas of the Global Forest Change map differed across years. These varying accuracies and area estimates should be considered when the Global Forest Change map is used for regional disturbance mapping. As expected, smaller disturbances were difficult to detect using both disturbance maps, resulting in a lower disturbance detection accuracy in areas dominated by small-scale disturbances. The mixed-effects models also indicated that the disturbance size was an influencing factor for correct detection in both maps. Although the Global Forest Change map can partially detect disturbances even if they are less than $1 \mathrm{ha}$, the map should be cautiously used because of its high commission error in small-scale disturbances. However, for disturbances larger than 3 ha, both disturbance maps achieved higher and comparable accuracies. In this context, the Global Forest Change map can be used for detecting larger disturbances. In areas dominated by small-scale disturbances, the Landsat data for detecting disturbances were coarse. High-spatial resolution data, such as Sentinel-2 data, might be used for achieving sufficient detection accuracies.

Supplementary Materials: The following are available online at http://www.mdpi.com/2072-4292/12/15/2438/s1.

Author Contributions: Conceptualization, K.S. and T.O.; methodology, K.S. and T.O.; software, K.S.; validation, K.S.; formal analysis, K.S. and T.O.; investigation, K.S.; resources, K.S.; data curation, K.S.; Writing-Original draft preparation, K.S.; Writing-Review and editing, K.S., T.O., and N.M.; visualization, K.S.; supervision, N.M. All authors have read and agreed to the published version of the manuscript.

Funding: This study was funded by the research grant of the Forestry and Forest Products Research Institute.

Acknowledgments: We thank the anonymous reviewers for their constructive comments.

Conflicts of Interest: The authors declare no conflict of interest.

\section{References}

1. Gibson, L.; Lee, T.M.; Koh, L.P.; Brook, B.W.; Gardner, T.A.; Barlow, J.; Peres, C.A.; Bradshaw, C.J.A.; Laurance, W.F.; Lovejoy, T.E.; et al. Primary forests are irreplaceable for sustaining tropical biodiversity. Nature 2011, 478, 378-381. [CrossRef] [PubMed]

2. Taubert, F.; Fischer, R.; Groeneveld, J.; Lehmann, S.; Müller, M.S.; Rödig, E.; Wiegand, T.; Huth, A. Global patterns of tropical forest fragmentation. Nature 2018, 554, 519. [CrossRef] [PubMed]

3. Margono, B.A.; Potapov, P.V.; Turubanova, S.; Stolle, F.; Hansen, M.C. Primary forest cover loss in Indonesia over 2000-2012. Nat. Clim. Chang. 2014, 4, 730-735. [CrossRef]

4. Frolking, S.; Palace, M.W.; Clark, D.B.; Chambers, J.Q.; Shugart, H.H.; Hurtt, G.C. Forest disturbance and recovery: A general review in the context of spaceborne remote sensing of impacts on aboveground biomass and canopy structure. J. Geophys. Res. Biogeosci. 2009, 114, G00E02. [CrossRef]

5. Brosofske, K.D.; Froese, R.E.; Falkowski, M.J.; Banskota, A. A Review of Methods for Mapping and Prediction of Inventory Attributes for Operational Forest Management. For. Sci. 2014, 60, 733-756. [CrossRef]

6. van Lierop, P.; Lindquist, E.; Sathyapala, S.; Franceschini, G. Global forest area disturbance from fire, insect pests, diseases and severe weather events. For. Ecol. Manag. 2015, 352, 78-88. [CrossRef]

7. Hirschmugl, M.; Gallaun, H.; Dees, M.; Datta, P.; Deutscher, J.; Koutsias, N.; Schardt, M. Methods for Mapping Forest Disturbance and Degradation from Optical Earth Observation Data: A Review. Curr. For. Rep. 2017, 3, 32-45. [CrossRef] 
8. Global Forest Observations Initiative Integration of remote-sensing and ground-based observations for estimation of emissions and removals of greenhouse gases in forests: Methods and guidance from the Global Forest Observations Initiative. UN Food Agric. Organ. 2016, 224, 1-224.

9. Wulder, M.A.; Loveland, T.R.; Roy, D.P.; Crawford, C.J.; Masek, J.G.; Woodcock, C.E.; Allen, R.G.; Anderson, M.C.; Belward, A.S.; Cohen, W.B.; et al. Current status of Landsat program, science, and applications. Remote Sens. Environ. 2019, 225, 127-147. [CrossRef]

10. Wulder, M.A.; Masek, J.G.; Cohen, W.B.; Loveland, T.R.; Woodcock, C.E. Opening the archive: How free data has enabled the science and monitoring promise of Landsat. Remote Sens. Environ. 2012, 122, 2-10. [CrossRef]

11. Kennedy, R.E.; Yang, Z.; Cohen, W.B. Detecting trends in forest disturbance and recovery using yearly Landsat time series: 1. LandTrendr-Temporal segmentation algorithms. Remote Sens. Environ. 2010, 114, 2897-2910. [CrossRef]

12. Huang, C.; Goward, S.N.; Masek, J.G.; Thomas, N.; Zhu, Z.; Vogelmann, J.E. An automated approach for reconstructing recent forest disturbance history using dense Landsat time series stacks. Remote Sens. Environ. 2010, 114, 183-198. [CrossRef]

13. Hermosilla, T.; Wulder, M.A.; White, J.C.; Coops, N.C.; Hobart, G.W. Regional detection, characterization, and attribution of annual forest change from 1984 to 2012 using Landsat-derived time-series metrics. Remote Sens. Environ. 2015, 170, 121-132. [CrossRef]

14. Verbesselt, J.; Hyndman, R.; Zeileis, A.; Culvenor, D. Phenological change detection while accounting for abrupt and gradual trends in satellite image time series. Remote Sens. Environ. 2010, 114, 2970-2980. [CrossRef]

15. Verbesselt, J.; Zeileis, A.; Herold, M. Near real-time disturbance detection using satellite image time series. Remote Sens. Environ. 2012, 123, 98-108. [CrossRef]

16. Zhu, Z.; Woodcock, C.E. Continuous change detection and classification of land cover using all available Landsat data. Remote Sens. Environ. 2014, 144, 152-171. [CrossRef]

17. Zhu, Z.; Zhang, J.; Yang, Z.; Aljaddani, A.H.; Cohen, W.B.; Qiu, S.; Zhou, C. Continuous monitoring of land disturbance based on Landsat time series. Remote Sens. Environ. 2020, 238, 111116. [CrossRef]

18. Brooks, E.B.; Thomas, V.A.; Wynne, R.H.; Coulston, J.W. Fitting the Multitemporal Curve: A Fourier Series Approach to the Missing Data Problem in Remote Sensing Analysis. IEEE Trans. Geosci. Remote Sens. 2012, 50, 3340-3353. [CrossRef]

19. Hughes, M.; Kaylor, S.; Hayes, D. Patch-based forest change detection from Landsat time series. Forests 2017, 8, 166. [CrossRef]

20. Zhao, K.; Wulder, M.A.; Hu, T.; Bright, R.; Wu, Q.; Qin, H.; Li, Y.; Toman, E.; Mallick, B.; Zhang, X.; et al. Detecting change-point, trend, and seasonality in satellite time series data to track abrupt changes and nonlinear dynamics: A Bayesian ensemble algorithm. Remote Sens. Environ. 2019, 232, 111181. [CrossRef]

21. Vogeler, J.C.; Slesak, R.A.; Fekety, P.A.; Falkowski, M.J. Characterizing over Four Decades of Forest Disturbance in Minnesota, USA. Forests 2020, 11, 362. [CrossRef]

22. Kennedy, R.E.; Yang, Z.; Braaten, J.; Copass, C.; Antonova, N.; Jordan, C.; Nelson, P. Attribution of disturbance change agent from Landsat time-series in support of habitat monitoring in the Puget Sound region, USA. Remote Sens. Environ. 2015, 166, 271-285. [CrossRef]

23. Murillo-Sandoval, P.J.; Hilker, T.; Krawchuk, M.A.; Van Den Hoek, J. Detecting and attributing drivers of forest disturbance in the Colombian Andes using Landsat time-series. Forests 2018, 9, 269. [CrossRef]

24. Nguyen, T.H.; Jones, S.D.; Soto-Berelov, M.; Haywood, A.; Hislop, S. A spatial and temporal analysis of forest dynamics using Landsat time-series. Remote Sens. Environ. 2018, 217, 461-475. [CrossRef]

25. Schleeweis, K.G.; Moisen, G.G.; Schroeder, T.A.; Toney, C.; Freeman, E.A.; Goward, S.N.; Huang, C.; Dungan, J.L. US National Maps Attributing Forest Change: 1986-2010. Forests 2020, 11, 653. [CrossRef]

26. Shimizu, K.; Ahmed, O.S.; Ponce-Hernandez, R.; Ota, T.; Win, Z.C.; Mizoue, N.; Yoshida, S. Attribution of Disturbance Agents to Forest Change Using a Landsat Time Series in Tropical Seasonal Forests in the Bago Mountains, Myanmar. Forests 2017, 8, 218. [CrossRef]

27. Nguyen, T.H.; Jones, S.D.; Soto-Berelov, M.; Haywood, A.; Hislop, S. Monitoring aboveground forest biomass dynamics over three decades using Landsat time-series and single-date inventory data. Int. J. Appl. Earth Obs. Geoinf. 2020, 84, 101952. [CrossRef] 
28. Ahmed, O.S.; Franklin, S.E.; Wulder, M.A.; White, J.C. Characterizing stand-level forest canopy cover and height using Landsat time series, samples of airborne LiDAR, and the Random Forest algorithm. ISPRS J. Photogramm. Remote Sens. 2015, 101, 89-101. [CrossRef]

29. Ota, T.; Ahmed, O.S.; Franklin, S.; Wulder, M.; Kajisa, T.; Mizoue, N.; Yoshida, S.; Takao, G.; Hirata, Y.; Furuya, N.; et al. Estimation of Airborne Lidar-Derived Tropical Forest Canopy Height Using Landsat Time Series in Cambodia. Remote Sens. 2014, 6, 10750-10772. [CrossRef]

30. Matasci, G.; Hermosilla, T.; Wulder, M.A.; White, J.C.; Coops, N.C.; Hobart, G.W.; Zald, H.S.J. Large-area mapping of Canadian boreal forest cover, height, biomass and other structural attributes using Landsat composites and lidar plots. Remote Sens. Environ. 2018, 209, 90-106. [CrossRef]

31. Pflugmacher, D.; Cohen, W.B.; Kennedy, R.E.; Yang, Z. Using Landsat-derived disturbance and recovery history and lidar to map forest biomass dynamics. Remote Sens. Environ. 2014, 151, 124-137. [CrossRef]

32. Matasci, G.; Hermosilla, T.; Wulder, M.A.; White, J.C.; Coops, N.C.; Hobart, G.W.; Bolton, D.K.; Tompalski, P.; Bater, C.W. Three decades of forest structural dynamics over Canada's forested ecosystems using Landsat time-series and lidar plots. Remote Sens. Environ. 2018, 216, 697-714. [CrossRef]

33. Zald, H.S.J.; Wulder, M.A.; White, J.C.; Hilker, T.; Hermosilla, T.; Hobart, G.W.; Coops, N.C. Integrating Landsat pixel composites and change metrics with lidar plots to predictively map forest structure and aboveground biomass in Saskatchewan, Canada. Remote Sens. Environ. 2016, 176, 188-201. [CrossRef]

34. Franklin, S.E.; Ahmed, O.S.; Wulder, M.A.; White, J.C.; Hermosilla, T.; Coops, N.C. Large Area Mapping of Annual Land Cover Dynamics Using Multitemporal Change Detection and Classification of Landsat Time Series Data. Can. J. Remote Sens. 2015, 41, 293-314. [CrossRef]

35. Turner, W.; Rondinini, C.; Pettorelli, N.; Mora, B.; Leidner, A.K.; Szantoi, Z.; Buchanan, G.; Dech, S.; Dwyer, J.; Herold, M.; et al. Free and open-access satellite data are key to biodiversity conservation. Biol. Conserv. 2015, 182, 173-176. [CrossRef]

36. Hansen, M.C.; Potapov, P.V.; Moore, R.; Hancher, M.; Turubanova, S.A.; Tyukavina, A.; Thau, D.; Stehman, S.V.; Goetz, S.J.; Loveland, T.R.; et al. High-resolution global maps of 21st-century forest cover change. Science 2013, 342, 850-853. [CrossRef]

37. Tamiminia, H.; Salehi, B.; Mahdianpari, M.; Quackenbush, L.; Adeli, S.; Brisco, B. Google Earth Engine for geo-big data applications: A meta-analysis and systematic review. ISPRS J. Photogramm. Remote Sens. 2020, 164, 152-170. [CrossRef]

38. Lwin, K.K.; Ota, T.; Shimizu, K.; Mizoue, N. Assessing the Importance of Tree Cover Threshold for Forest Cover Mapping Derived from Global Forest Cover in Myanmar. Forests 2019, 10, 1062. [CrossRef]

39. Sannier, C.; McRoberts, R.E.; Fichet, L.-V. Suitability of Global Forest Change data to report forest cover estimates at national level in Gabon. Remote Sens. Environ. 2016, 173, 326-338. [CrossRef]

40. McRoberts, R.E.; Vibrans, A.C.; Sannier, C.; Næsset, E.; Hansen, M.C.; Walters, B.F.; Lingner, D.V. Methods for evaluating the utilities of local and global maps for increasing the precision of estimates of subtropical forest area. Can. J. For. Res. 2016, 46, 924-932. [CrossRef]

41. Zhang, D.; Wang, H.; Wang, X.; Lü, Z. Accuracy assessment of the global forest watch tree cover 2000 in China. Int. J. Appl. Earth Obs. Geoinf. 2020, 87, 102033. [CrossRef]

42. Galiatsatos, N.; Donoghue, D.N.M.; Watt, P.; Bholanath, P.; Pickering, J.; Hansen, M.C.; Mahmood, A.R.J. An Assessment of Global Forest Change Datasets for National Forest Monitoring and Reporting. Remote Sens. 2020, 12, 1790. [CrossRef]

43. Melo, J.B.; Ziv, G.; Baker, T.R.; Carreiras, J.M.B.; Pearson, T.R.H.; Vasconcelos, M.J. Striking divergences in Earth Observation products may limit their use for REDD+. Environ. Res. Lett. 2018, 13, 104020. [CrossRef]

44. Hamunyela, E.; Brandt, P.; Shirima, D.; Do, H.T.T.; Herold, M.; Roman-Cuesta, R.M. Space-time detection of deforestation, forest degradation and regeneration in montane forests of Eastern Tanzania. Int. J. Appl. Earth Obs. Geoinf. 2020, 88, 102063. [CrossRef]

45. Milodowski, D.T.; Mitchard, E.T.A.; Williams, M. Forest loss maps from regional satellite monitoring systematically underestimate deforestation in two rapidly changing parts of the Amazon. Environ. Res. Lett. 2017, 12, 094003. [CrossRef]

46. Bos, A.B.; De Sy, V.; Duchelle, A.E.; Herold, M.; Martius, C.; Tsendbazar, N.-E. Global data and tools for local forest cover loss and REDD+ performance assessment: Accuracy, uncertainty, complementarity and impact. Int. J. Appl. Earth Obs. Geoinf. 2019, 80, 295-311. [CrossRef] 
47. Stehman, S.V.; Foody, G.M. Key issues in rigorous accuracy assessment of land cover products. Remote Sens. Environ. 2019, 231, 111199. [CrossRef]

48. Olofsson, P.; Foody, G.M.; Herold, M.; Stehman, S.V.; Woodcock, C.E.; Wulder, M.A. Good practices for estimating area and assessing accuracy of land change. Remote Sens. Environ. 2014, 148, 42-57. [CrossRef]

49. Olofsson, P.; Foody, G.M.; Stehman, S.V.; Woodcock, C.E. Making better use of accuracy data in land change studies: Estimating accuracy and area and quantifying uncertainty using stratified estimation. Remote Sens. Environ. 2013, 129, 122-131. [CrossRef]

50. Stehman, S.V. Estimating area from an accuracy assessment error matrix. Remote Sens. Environ. 2013, 132, 202-211. [CrossRef]

51. Wade, C.M.; Austin, K.G.; Cajka, J.; Lapidus, D.; Everett, K.H.; Galperin, D.; Maynard, R.; Sobel, A. What is Threatening Forests in Protected Areas? A Global Assessment of Deforestation in Protected Areas, 2001-2018. Forests 2020, 11, 539. [CrossRef]

52. Santika, T.; Wilson, K.A.; Budiharta, S.; Kusworo, A.; Meijaard, E.; Law, E.A.; Friedman, R.; Hutabarat, J.A.; Indrawan, T.P.; St. John, F.A.V.; et al. Heterogeneous impacts of community forestry on forest conservation and poverty alleviation: Evidence from Indonesia. People Nat. 2019, 1, 204-219.

53. Oldekop, J.A.; Sims, K.R.E.; Karna, B.K.; Whittingham, M.J.; Agrawal, A. Reductions in deforestation and poverty from decentralized forest management in Nepal. Nat. Sustain. 2019, 2, 421-428. [CrossRef]

54. Linke, J.; Fortin, M.-J.; Courtenay, S.; Cormier, R. High-resolution global maps of $21^{\text {st }}$-century annual forest loss: Independent accuracy assessment and application in a temperate forest region of Atlantic Canada. Remote Sens. Environ. 2017, 188, 164-176. [CrossRef]

55. Baumann, M.; Ozdogan, M.; Wolter, P.T.; Krylov, A.; Vladimirova, N.; Radeloff, V.C. Landsat remote sensing of forest windfall disturbance. Remote Sens. Environ. 2014, 143, 171-179. [CrossRef]

56. Cohen, W.B.; Yang, Z.; Stehman, S.V.; Schroeder, T.A.; Bell, D.M.; Masek, J.G.; Huang, C.; Meigs, G.W. Forest disturbance across the conterminous United States from 1985-2012: The emerging dominance of forest decline. For. Ecol. Manage. 2016, 360, 242-252. [CrossRef]

57. Shimizu, K.; Ota, T.; Mizoue, N. Detecting Annual Harvested Area Using Landsat Time Series Data on the Main Island of Kyushu. J. Jpn. For. Soc. 2020, 102, 15-23. [CrossRef]

58. Kennedy, R.E.; Yang, Z.; Gorelick, N.; Braaten, J.; Cavalcante, L.; Cohen, W.B.; Healey, S. Implementation of the LandTrendr Algorithm on Google Earth Engine. Remote Sens. 2018, 10, 691. [CrossRef]

59. Gorelick, N.; Hancher, M.; Dixon, M.; Ilyushchenko, S.; Thau, D.; Moore, R. Google Earth Engine: Planetary-scale geospatial analysis for everyone. Remote Sens. Environ. 2017, 202, 18-27. [CrossRef]

60. Shimizu, K.; Ota, T.; Mizoue, N.; Yoshida, S. A comprehensive evaluation of disturbance agent classification approaches: Strengths of ensemble classification, multiple indices, spatio-temporal variables, and direct prediction. ISPRS J. Photogramm. Remote Sens. 2019, 158, 99-112. [CrossRef]

61. Huang, C.; Wylie, B.; Yang, L.; Homer, C.; Zylstra, G. Derivation of a tasselled cap transformation based on Landsat 7 at-satellite reflectance. Int. J. Remote Sens. 2002, 23, 1741-1748. [CrossRef]

62. Farr, T.G.; Rosen, P.A.; Caro, E.; Crippen, R.; Duren, R.; Hensley, S.; Kobrick, M.; Paller, M.; Rodriguez, E.; Roth, L.; et al. The Shuttle Radar Topography Mission. Rev. Geophys. 2007, 45, RG2004. [CrossRef]

63. Arévalo, P.; Olofsson, P.; Woodcock, C.E. Continuous monitoring of land change activities and post-disturbance dynamics from Landsat time series: A test methodology for REDD+ reporting. Remote Sens. Environ. 2019, 238, 111051. [CrossRef]

64. Fortin, J.A.; Cardille, J.A.; Perez, E. Multi-sensor detection of forest-cover change across 45 years in Mato Grosso, Brazil. Remote Sens. Environ. 2020, 238, 111266. [CrossRef]

65. Stehman, S.V. Estimating area and map accuracy for stratified random sampling when the strata are different from the map classes. Int. J. Remote Sens. 2014, 35, 4923-4939. [CrossRef]

66. Pickens, A.H.; Hansen, M.C.; Hancher, M.; Stehman, S.V.; Tyukavina, A.; Potapov, P.; Marroquin, B.; Sherani, Z Mapping and sampling to characterize global inland water dynamics from 1999 to 2018 with full Landsat time-series. Remote Sens. Environ. 2020, 243, 111792. [CrossRef]

67. Hawbaker, T.J.; Vanderhoof, M.K.; Schmidt, G.L.; Beal, Y.-J.; Picotte, J.J.; Takacs, J.D.; Falgout, J.T.; Dwyer, J.L. The Landsat Burned Area algorithm and products for the conterminous United States. Remote Sens. Environ. 2020, 244, 111801. [CrossRef] 
68. Long, T.; Zhang, Z.; He, G.; Jiao, W.; Tang, C.; Wu, B.; Zhang, X.; Wang, G.; Yin, R. 30 m Resolution Global Annual Burned Area Mapping Based on Landsat Images and Google Earth Engine. Remote Sens. 2019, 11, 489. [CrossRef]

69. Gao, F.; Masek, J.; Wolfe, R.E. Automated registration and orthorectification package for Landsat and Landsat-like data processing. J. Appl. Remote Sens. 2009, 3, 033515.

70. Cochran, W.G. Sampling Techniques, 3rd ed.; John Willey \& Sons Inc.: New York, NY, USA, 1977.

71. Padilla, M.; Olofsson, P.; Stehman, S.V.; Tansey, K.; Chuvieco, E. Stratification and sample allocation for reference burned area data. Remote Sens. Environ. 2017, 203, 240-255. [CrossRef]

72. Gibson, R.; Danaher, T.; Hehir, W.; Collins, L. A remote sensing approach to mapping fire severity in south-eastern Australia using sentinel 2 and random forest. Remote Sens. Environ. 2020, 240, 111702. [CrossRef]

73. R Core Team R: A Language and Environment for Statistical Computing. R Found. Stat. Comput. Vienna 2019.

74. Cohen, W.B.; Healey, S.; Yang, Z.; Stehman, S.; Brewer, C.; Brooks, E.; Gorelick, N.; Huang, C.; Hughes, M.; Kennedy, R.; et al. How similar are forest disturbance maps derived from different Landsat time series algorithms? Forests 2017, 8, 98. [CrossRef]

75. Cohen, W.B.; Healey, S.P.; Yang, Z.; Zhu, Z.; Gorelick, N. Diversity of Algorithm and Spectral Band Inputs Improves Landsat Monitoring of Forest Disturbance. Remote Sens. 2020, 12, 1673. [CrossRef]

76. Healey, S.P.; Cohen, W.B.; Yang, Z.; Brewer, C.K.; Brooks, E.B.; Gorelick, N.; Hernandez, A.J.; Huang, C.; Hughes, M.J.; Kennedy, R.E.; et al. Mapping forest change using stacked generalization: An ensemble approach. Remote Sens. Environ. 2018, 204, 717-728. [CrossRef]

77. DeVries, B.; Verbesselt, J.; Kooistra, L.; Herold, M. Robust monitoring of small-scale forest disturbances in a tropical montane forest using Landsat time series. Remote Sens. Environ. 2015, 161, 107-121. [CrossRef]

78. Sulla-Menashe, D.; Kennedy, R.E.; Yang, Z.; Braaten, J.; Krankina, O.N.; Friedl, M.A. Detecting forest disturbance in the Pacific Northwest from MODIS time series using temporal segmentation. Remote Sens. Environ. 2014, 151, 114-123. [CrossRef]

79. Olofsson, P.; Arévalo, P.; Espejo, A.B.; Green, C.; Lindquist, E.; McRoberts, R.E.; Sanz, M.J. Mitigating the effects of omission errors on area and area change estimates. Remote Sens. Environ. 2020, 236, 111492. [CrossRef]

(C) 2020 by the authors. Licensee MDPI, Basel, Switzerland. This article is an open access article distributed under the terms and conditions of the Creative Commons Attribution (CC BY) license (http://creativecommons.org/licenses/by/4.0/). 